\title{
Value Chain Development as Alternative Method For Mapping Waste Management Muhammad Saiful Hakim ${ }^{1}$, Imam Baihaqi ${ }^{2}$, Aang Kunaifi ${ }^{3}$
}

\author{
Department of Business Management, Institute of Technology Sepuluh Nopember, Surabaya, Indonesia ${ }^{1}$
}

\begin{abstract}
Solid Waste management begin at the household as waste of consumption and ended as a new form of waste product or recycling. Based on its value chain the subsequent process will have distict differences with manufacturing product. Value chain of manufacturing product will characterize as value added chain along the chain, where every side of the chain will generate positive chain. In the other hand, some parties of waste management value chain will negative value existed. Some parties in this chain will generate negative value solely because they must establish some cost for wipe the waste. Dissimilarities between value chain on product and waste will contribute to discrepancy between parties. Main purpose of this research is to identify value chain from solid waste management using value chain development. Another purpose to accomplished is to resolve discrepancy in value chain. Research results shown that household is the parties that experiences negative value. To minimize the discrepancies there should be an action towards household
\end{abstract}

Keywords: Value Chain; Value Chain Development; Waste Management.

\section{Introduction}

Value Chain is a concept that had been circulate since seminal work of porter in 1980 (Porter, 1980). Value chain analyse value stream between system in firm and interfirm. Furthermore, value chain will divided value added activities into primary and supported activities. Value chain concept also provide generic value adding activities of the firm in production. This arrangement is adequate for firm to understand their position in whole set of value chain. Some firm usually only a part of large activities in the whole value added system. Achieving sustainable competitive advantages requires firm to understand not only their part of value chain in which it contributes(Shank \& Govindarajan, 1993).

Value chain in most cases held for production of product or services. Value chain in product or services will characterise as value added stream, where each activities will subsequently adding value. In the other hand for some product such as waste there will poses challenge to employ alue chain. In waste management there are system with negative value in chain. Surely this are against the principle of value chain as value added system. There are few cases adopting the value chain for waste management(Associates, 2010; Chintan, 2003; van den Berg, 2014). Some of the cases only use part of value chain for their analysis. There is another issues using value chain for waste management. Value chain for product usually began at producer value (Factory) that flows to consumer value(Household). For waste the value chain is from the Household( Producer of waste) that flows to factory (Consumer Of Waste ).

Adopting value chain in different environment require different approach. This paper uses Value chain development as way to adopt value chain in waste management. Value chain management originated from tool that commonly used by NGO for identify constraints to value chain per- formance, which may adversely impact the poor, so that interventions can be designed and implemented to address these constraints(International Labour Organisation, 2015; UNIDO, 2011). In a market economy, value chains are competing against each other. From the perspective of development agencies, value chain development is the support provided to this process, which aims to identify and address the systemic constraints that inhibit inclusive growth.

In Surabaya waste management involve government agency, society and private sector, and NGO. Government agency is represent by Dinas Kebersihan and pertamanan (Government Agency that responsible for waste management), household as producers of waste is part of society, private sector is factory or private companies that recognize profit from recycling or waste management, and the last part is NGO are involve NGO in Surabaya with waste management objective such as waste bank. Nowadays,

\footnotetext{
1 ms_hakim@mb.its.ac.id
} 
theres already numerous of recycling plant and waste bank existed, as noted from Dinas Kebersihan dan Pertamanan there are 246 waste bank in Surabaya. However if we consider the number of waste in surabaya that in one day there are 2000 tonnes new waste existed, that number of waste bank is still small(Fransilia, 2015). There should be any action to settling the waste problem in surabaya.

This study use value chain developnment to seek where is the action should take place in the manner of value chain of the waste management. Value chain in this research will focus on drinking water bottle. When the limitation is set there are concern that the analysis will not represent the reality, Still we believe that because the product we choose will representate the reality since this product has a considerable potential either for recycling as handicraft or to used in recycling factory..

\section{Literature Review}

Value chain views organization as collaboratoion of process that poses as a system that will have sub-system and with subsequent of trasnformation processes of inputs and outpur that involve the acquisitionand consumption of resources(Sweeney, 2009). The resource the system used includes, money, labour, materials, equipment, buildings, land, administration and management. value chain activities will determines how the organizaion perform. Generic views of value chain is to defined it in business unit level. Because value chain will focus on product, specially in chain of activities that gives product added value along the activities (Porter, 1985). Chain of activities in business unit level consist of generic activities that could be illustrated as diamond cutter shaped (figure 1) where each sub system have a similar mission to added value for the product.

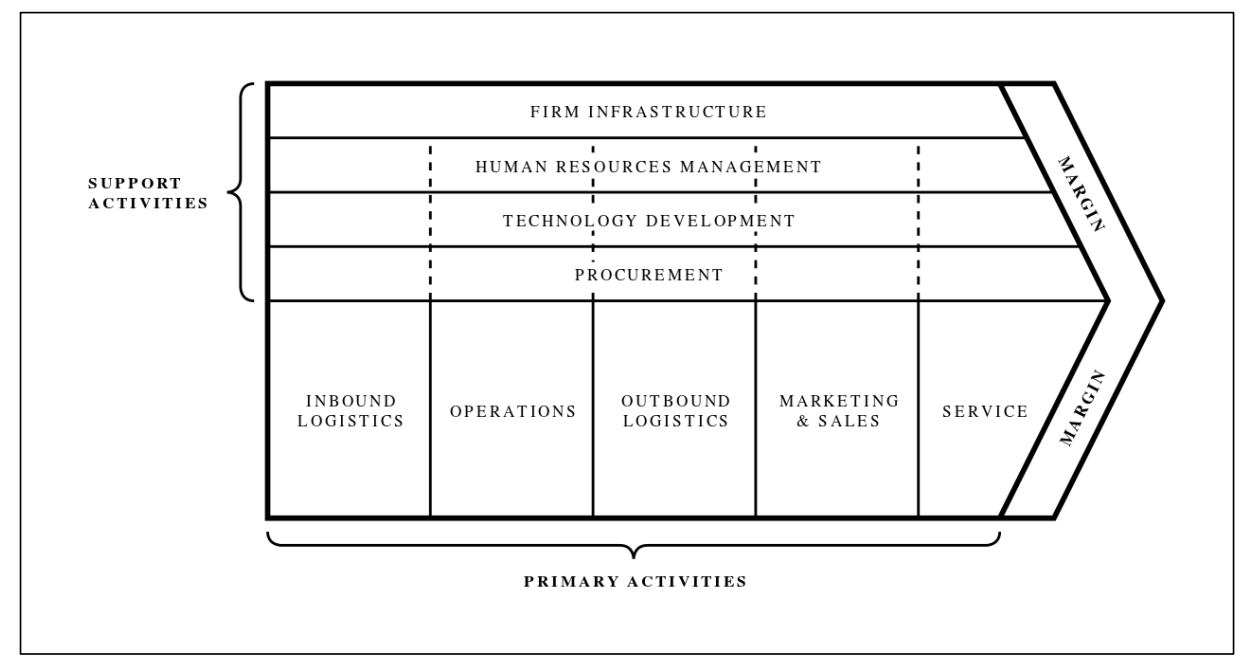

Source: Porter(1985)

Figure 1. Value Chain Business Unit

The concept of value chain provide strategic management ability to pinpoint strategic development to achieve sustainable competitive advantage. To achieve the advantages a firm must understand each of its activities. The activities could be divided to 2 activities level. Primary activities and suport activities. There are:

Primary activities

a. Inbound Logistics: movement of inputs such as materials, parts,

b. Operations: core process of transform inputs into outputs

c. Outbound Logistics: transporting final product to customer

d. Marketing and Sales: process of selling and offering product to customer

e. Service: process required to keep the product/service

Support activities

f. Procurement: process of acquire input

g. Human Resources Management: process involving manage human resources

h. Technological Development: technology used in transform input for output

i. Infrastructure: activities that involves basic resource of the firm 
In the development value chain not only used capture internal chain. Value chain used to capture gap between parties on the whole supply chain ((Dekker, 2003). This process is growing to Value chain development. Value chain development originated from tool that commonly used by NGO for identify constraints to value chain performance, which may adversely impact the poor, so that interventions can be designed and implemented to address these constraints(International Labour Organisation, 2015; UNIDO, 2011). In a market economy, value chains are competing against each other. From the perspective of development agencies, value chain development is the support provided to this process, which aims to identify and address the systemic constraints that inhibit inclusive growth

\section{Methodology}

This paper using Value chain development as tool research to identified initiative action needed to resolve discrepancies in value chain this method. The data collected in this paper are primary and secondary information. Primary data collected by interviewing respondent that consist of government agency, Household, waste pickers, waste bank, flea broker, recycler, and recyling industries in surabaya along with additional respondent if needed. The Secondary data include pricelist from waste bank, waste data, and budgeting data for government agency. There are 4 stage researches that carried in this paper. The stages of researches is illustrated in figure 1:

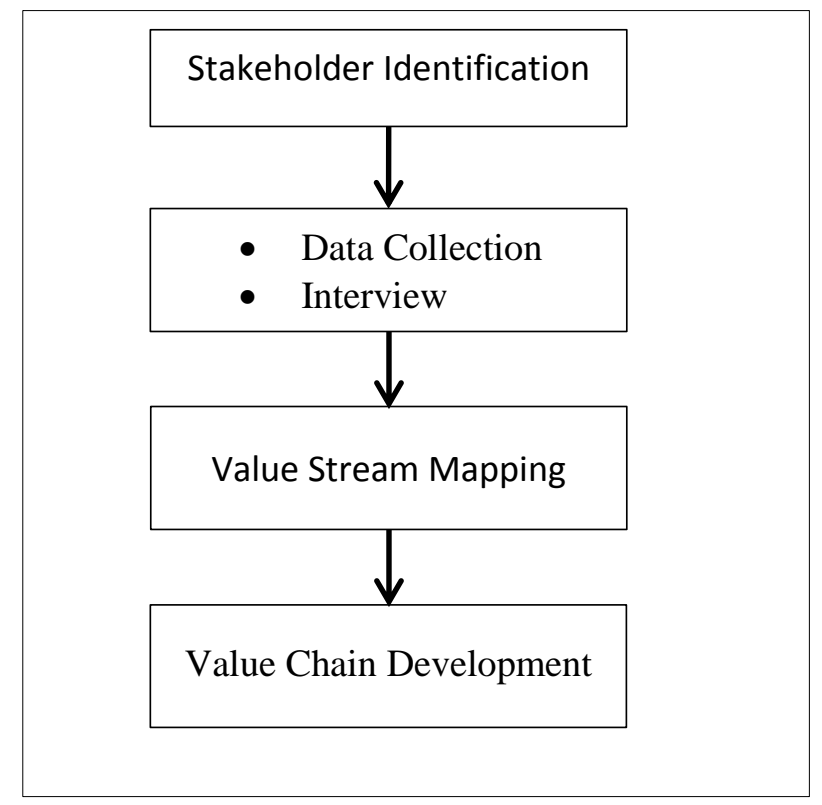

Figure 1. Stage Of Research

\section{Result and Discussion}

Just likes in most cases, composition of waste in Surabaya composed mainly with organic waste followed with solid waste like plastic, paper and small number of ceramic, glass and metal. Small number in composition does not mean small number in term of weight. Waste production in Surabaya for a day had exceeded 2000 tonnes, $1 \%$ in composition converted to weight become 20 tonnes a day. The percentage composition of waste in Surabaya along with their estimation weight per day can be seen in table 1 .

In the last few year amount of Surabaya waste had decreased as a result of the clean and green program initiated by government of Surabaya. The program includes, training activities that focused on reducing waste specially organic waste, competition between district related to community based livelihood enhancement. This programme achieved great success, the management model has been transferred to other cities internationally(Gervasi, 2012). 
Table 1 : Waste Composition in Surabaya

\begin{tabular}{|c|c|c|c|}
\hline \multirow{2}{*}{ No } & \multirow{2}{*}{ Waste Composition } & \multirow{2}{*}{$\begin{array}{c}\text { Percentage } \\
\%)\end{array}$} & \multirow{2}{*}{$\begin{array}{c}\text { Tonnes } \\
\text { / Day }\end{array}$} \\
\hline & & & \\
\hline 1 & Organic Waste & $54,31 \%$ & 1.086 \\
\hline 2 & Wood/ Wood Product & $1,61 \%$ & 32 \\
\hline 3 & Leather & $1,19 \%$ & 24 \\
\hline 4 & Rubber & $1,14 \%$ & 23 \\
\hline 5 & Plastic & $19,44 \%$ & 389 \\
\hline 6 & Paper / Paper Material & $14,63 \%$ & 293 \\
\hline 7 & Fabric / Textile & $1,47 \%$ & 29 \\
\hline 8 & Glass & $1,12 \%$ & 22 \\
\hline 9 & Ceramic & $0,17 \%$ & 3 \\
\hline 10 & Metal & $0,48 \%$ & 10 \\
\hline 11 & Hazardous Material & $0,86 \%$ & 17 \\
\hline 12 & Others & $3,59 \%$ & 72 \\
\hline \multicolumn{2}{|r|}{ Totals } & $100,00 \%$ & 2.000 \\
\hline
\end{tabular}

Source : Dinas Kebersihan dan Pertamanan Kota Surabaya

Even though clean and green program is succes there still significant amount of waste that potential to recyling. In 2014 after the program is initiated, proportion of waste processing on waste origin is still on $25 \%$. The complete percentage of waste processing is written on table 2 . this mean that there are still a lot people of Surabaya that don't know or never sorting their waste.

Table 2 : Proportion of Waste Processed in Surabaya

\begin{tabular}{lrl}
\hline Location & M3 / Hari & Percentage \\
\hline Processed on Waste Source & 2.488 & $25 \%$ \\
Processed on temporary Dump Waste & 1.583 & $16 \%$ \\
Transported to Final Dump Waste & 5.239 & $54 \%$ \\
Unprocessed & 452 & $5 \%$ \\
Total & 9.762 & 1 \\
\hline Source : Dinas Kebersihan dan Pertamanan Surabaya
\end{tabular}

\section{Waste Management Chain}

In respects to recycling process there's only few type of waste that can be used to recycling. Plastic believed to be most precious on term of recycling. Plastics also have significant amount in number of waste of product. Based on that fact this research focused the value chain to plastic waste. In Surabaya there are 8 parties that involved in waste management of plastic waste. There are :

1. Household : Household is primary producer of waste that derived from their consumption activity. In this chain the regular action from them is by putting their waste In their trash box.

2. Garbageman : garbageman is paid by district (with the money that collected from every household) to collect the waste from household trash box and put them to Temporary Dump Site.

3. Waste Transporting: Waste transporting solely duty is to transport waste from temporary dump site to final dump site. Waste transporting is operated by Dinas Kebersihan dan Pertamanan.

4. Waste Bank member : there is a chance that household is member of waste bank. As waste bank member they will sort there waste independently and give it to waste bank.

5. Waste Bank : waste bank will receive sorted waste from their member and sold it either to flea merchant or to factory that utilize plastic waste.

6. Flea Picker : their job is to sort waste either from waste box or from final dump Site, usually they don't pay to any person for waste they take. 
7. Flea merchant : flea merchant is merchant with specialist for buying and selling sorted wasted. Usually they already have price list on every used item.

8. Recycling Plant: This kind of Factory use sorted waste as their material.

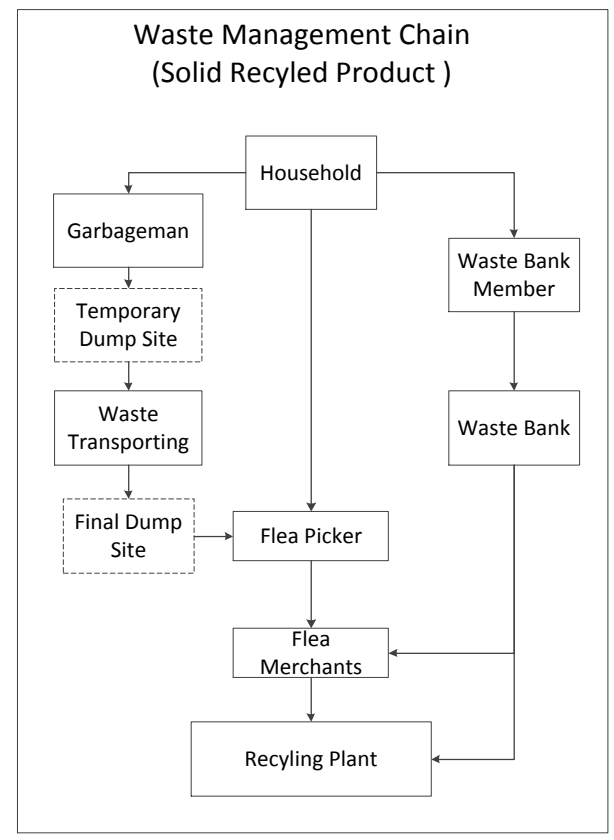

Figure 2. Waste Management Chain

\section{Waste Value Chain}

In waste management value chain there will value that coming not from real value or Price,(Household value) we will measuring its value using estimation derived from household contribution for waste management. Surely it's not common practice to use for value chain, But since household never realize this value we believed this is only way to obtain the value. In average midsize household have to spent Rp $22.500,00$ per month for waste contribution government and to district. If we divide this number with average number of plastic waste in the household per month $(71,10 \mathrm{Kg})$ we will get $\mathrm{Rp} 111,17$. Other value in chain obtained more easily because we can use real value or price.

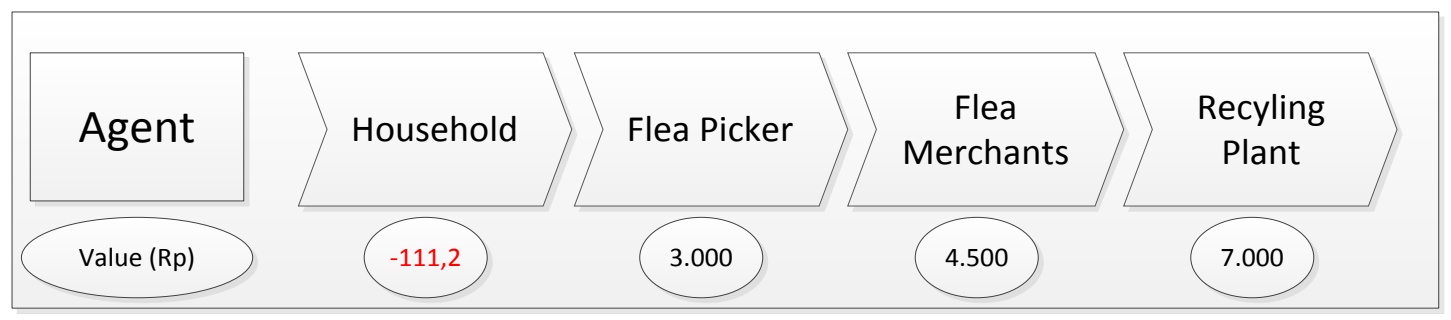

Figure 3. Value Chain of Waste (Regular)

As ilustrated in FIgure 3. We could seen that there are gradually increase of value along the chain. Just as expected, along the chain there is an agent that recognize negative value. The reason of this result is quite clear. Household is an agent that have to spent some cost to remove their waste. On contrary other agent in the value chain acquiring positive value chain because they can exploit the waste. If the household in value chain is a member of waste bank there will be improvement in their value chain because they will replace flea picker position as agent that gaining value. as waste bank member household have an opportunity to improve their position in value chain, as pictured in diagram 4 . If household contribute in value chain as waste bank member, they will offset their cost with the benefit they reap. 


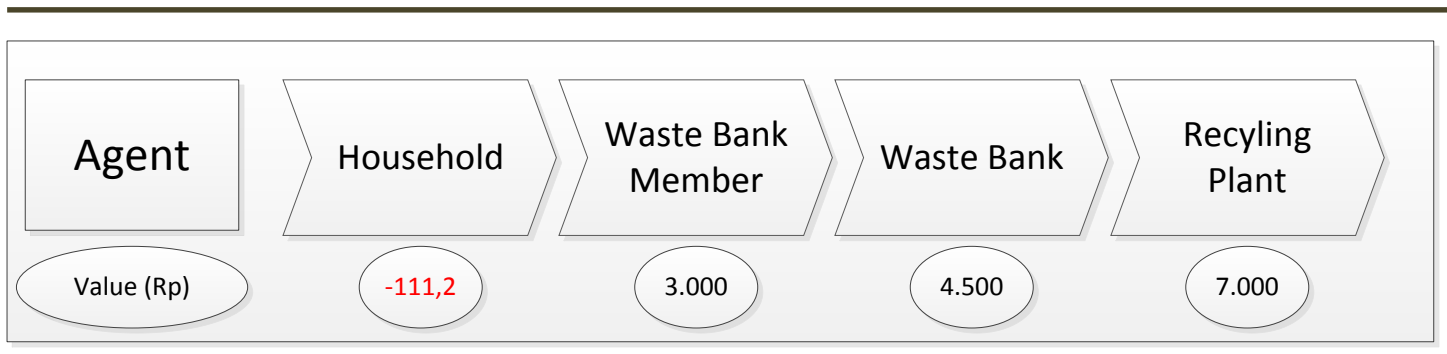

Figure 4. Value Chain of Waste (With Waste Bank)

When the household aware that become waste bank member is beneficial its logic to see growth in number of waste bank member. However even with the growing number of waste bank in surabaya the number of waste bank member still far from expected. There are few probable reason to this event. Involving in waste bank for some people is uncomfortable because rule that apply for its member usually is strict and binding for the membe, for example there are some waste bank that only allowed their member to sell the item they collect in spesific time. So for them the action needed for them to increase their position in value chain is to recycle or sorting their waste independently.

In value chain development the focus is to be minimize gap between member in value chain. In this case the focus is in the household. There should be an action regarding household position in value chain, the action that can be taken is:

1. Increase household involvement in waste bank member

2. Provide all household wih the capability to sort and recycle their waste

3. Provide infrastructure for household to sort their waste

\section{Conclusions}

Value chain analysis pictured the value that pereived by member in the waste chain. The result shown that from all the member in chain, household is the member that suffering negative value because cost that relate with waste process. For improve their position there should be an action to alter the chain that incllude promote household to become waste bank member and support the program for household to sort their waste independently.

\section{References}

Associates, W. (2010). Value Chain Analysis of Solid Waste Management for Youth Engagement in Service Delivery ( Yes ) Program in Accra, (April 2010).

Chintan. (2003). Space for Waste - Planning for the Informal Recycling Sector, 23. Retrieved from http://www.chintan-india.org/documents/research_and_reports/chintan_study_space_for_waste.pdf

Dekker, H. C. (2003). Value chain analysis in interfirm relationships: a field study. Management Accounting Research, 14, 1-23. http://doi.org/10.1016/S1044-5005(02)00067-7

Fransilia, M. (2015). Sampah Surabaya 2.000 Ton Tiap Hari, Hanya 500 Ton Diolah - Surya. Retrieved July 8, 2016, from http://surabaya.tribunnews.com/2015/05/11/sampah-surabaya-2000-ton-tiap-harihanya-500-ton-diolah

Gervasi, M. Surabaya, Indonesia: Green and clean initiative (2012).

International Labour Organisation. (2015). Value Chain Development For Decent Work - How to create employment and improve working conditions in targeted sectors (2nd ed.). International Labour Organization.

Porter, M. E. (1980). Competitive strategy (Vol. 1). The Free Press. Retrieved from http://books.google.com.au/books?id=QN0kyeHXtJMC\&pg=PR16\&dq=intitle:Competitive+Strate gy+Michael+Porter\&cd=1\&source=gbs_apilnpapers2://publication/uuid/03E8AAB4-AB47-420980C2-A4FFDCD1BC8A

Porter, M. E. (1985). Competitive Advantage. Strategic Management. http://doi.org/10.1108/eb054287

Shank, J. K., \& Govindarajan, V. (1993). Strategic Cost Management. The Free Press.

Sweeney, E. (2009). Supply Chain Management and the Value Chain. Transport and Logistics, 10(2), 1315. Retrieved from http://arrow.dit.ie/nitloth

UNIDO. (2011). Pro-poor Value Chain Development. United Nations Industrial Development Organization, Vienna, Austria. United Nations Industrial Development Organization. http://doi.org/10.1057/9781137373755.0007 
van den Berg, S. (2014). Integration of the informal sector in PET bottle collection and recycling: South Africa, Ecuador, and Columbia. Retrieved from http://www.waste.nl 
